\title{
Performance of Acerola, Malpighia punicifolia L., in the Coffee Region of Puerto Rico'
}

\author{
Tara Singh-Dhaliwal and Anibal Torres-Sepúlveda ${ }^{2}$
}

\section{INTRODUCTION}

The accrola (Malpighia punicifolia L.) is noted for its vitamin C-rich fruits which are utilized in many ways. lor this reason it has become a popular fruit plant in home gardens in all parts of Puerto Rico. It is also grown on a commercial scale for its vitamin $\mathrm{C}$-rich juice for use by the fruit-juice canneries and in baby foods.

Information about various aspects of accrola-growing in different regions of Puerto Rico has been published $(2,3,4,5) .{ }^{3}$ However, no experimental study on acerola production in the central-western mountainous region, commonly known as the Coffee Region, has been carried on.

In order to study the performance of acerola in the Coffee Region an experimental planting of it was established in January 1954, at Castañer in the centre of this Region. The results of this experimental planting during the past 7 years as to the growth characters of the trees, fruit yield, fruit characters, discases and insect pests, and utilization of fruits, are briefly described.

\section{PIROCEDUIRES}

ESTABLIHIMENT OF THE IXXPEIMENTAL PLANTING

When this investigation was initiated acerola clone B-17 was considered highly promising for commercial production (1). Therefore, seed for establishing the experimental planting at Castaner were taken from it.

The seed were sown in January 1954 in 4-inch earthern pots containing a loose medium. When the seedlings were about 3 inches high they were planted in the nursery 3 feet apart. When they were about 1 foot high 30 of them were planted at their permanent places in the field in an Alonso clay soil with a pH of about 5.0. The plants were spaced 8 feet apart following the scluare system (fig. 1).

1 This investigation was carried on under the Federal-Grant Research Project Hatch 94, Plant Int roductions and Development of New Crops.

2 Associate Plant Breeder and Research Assistant, respectively, Agricultural Experiment Station, University of Pureto Rico, Río Piedras, P.R. The authors are grateful to J. Véle\%-Fortuño, Head, Plant Breeding Department; Roy O. Woodbury, Taxonomist, and the personnel of the Central Analytical Laboratory and the Castaner Substation of the Agricultural Experiment Station, for assistance during the course of this investigation.

${ }^{3}$ Italic numbers in parentheses refer to literature cited p. 204. 


\section{general cultural practices}

In order to avoid soil erosion the planting was not cultivated. However, the weeds were frequently cut at a height of about 2 inches from the ground.

Up to 2 years of age the plants were occasionally lightly irrigated during lengthy dry periods. The water for this purpose was brought in cans from a nearloy stream. Mulch of dry grass was also applied around the plants.

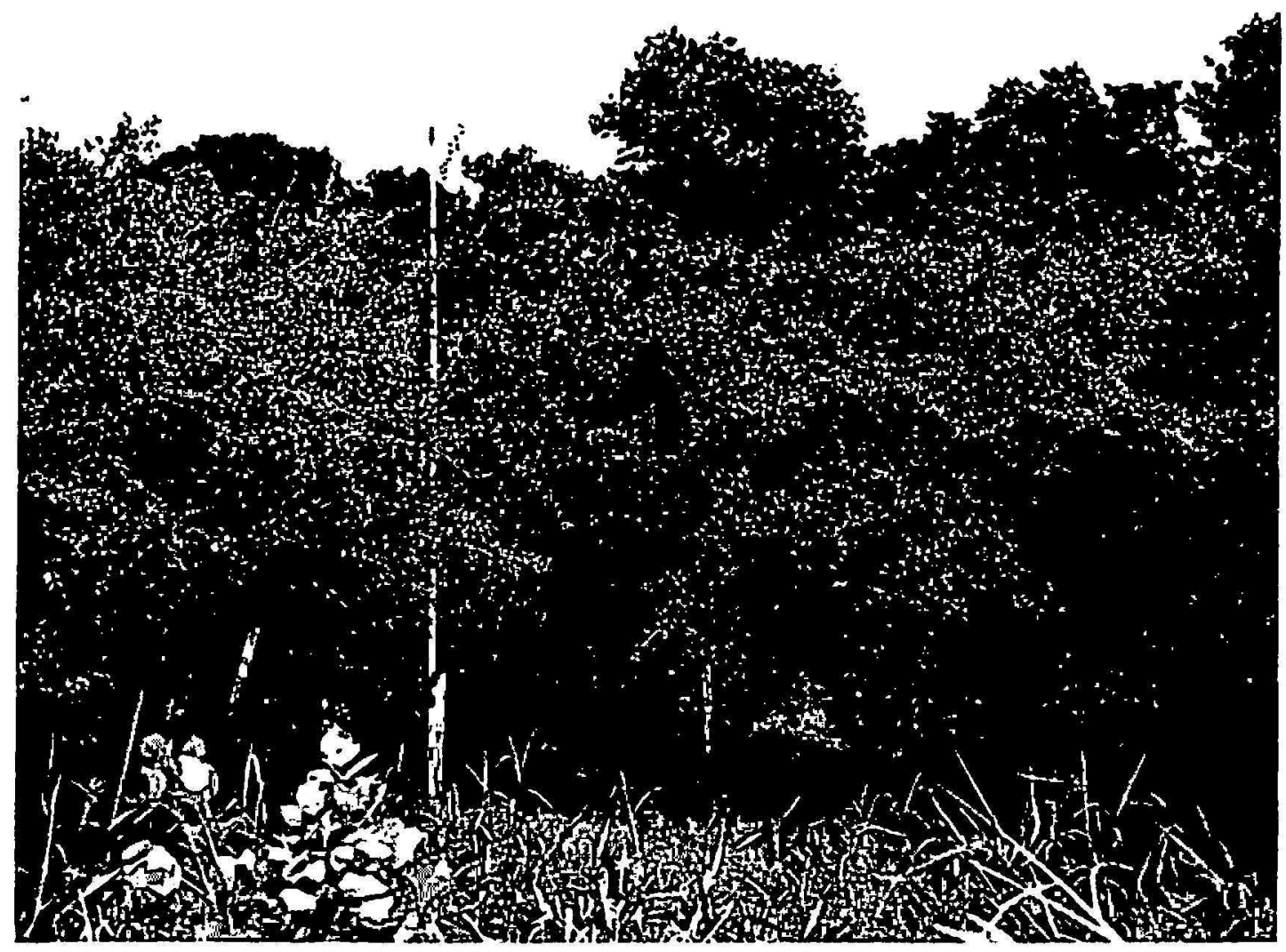

Fıg. 1.-Seven-year-old experimental acerola planting at the Agricultural lixperiment Substation, Castañer, P.R.

After they reached 2 years of age the plantings did not require irrigation or mulch.

During the first year a complete fertilizer 9-10-5, or ammonium sulfate, or a mixture of the two in the ratio of 1 to 1 by weight, was applied at the rate of 1 to 2 ounces per plant every 2 to 3 months, depending upon rainfall. As the plants grew older the quantity of fertilizer applied to them was gradually increased. Six-year-old plants were given 2 to 3 pounds of 9-10-5) fertilizer each every 2 to 3 months. In addition to this 1 to 2 pounds of ammonium sulfate fertilizer were also applied annually. Application of 8 to 10 pounds of rotten coffee pulp per plant once a year was also observed to be beneficial to the bearing plants. 
It was desired to know the natural size and shape of the plants for determining the suitable distance of planting and method of pruning them. Therefore they were allowed to grow without cutting or disturbing their natural growth in any way.

\section{RESULTS}

\section{GROWTH CHARACTERS OF 5-YEAR-OLD TREES}

The height of the trees varied from 76.0 to 132.0 inches and averaged 100.4 inches. Most of the trees which generally yielded above average also had a height above average. Most of them could be easily bent and therefore could be harvested without the use of ladders. Some of them when more than 5 years old grew much taller and it was difficult to harvest the crop from them. Therefore, it seems desirable that the trees be pruned so that they do not grow higher than about 120 inches in order to facilitate the harvesting of the crop.

The diameter of the canopies of the trees varied from 73.0 to 157.0 inches and averaged 114.8. Most of the trees generally yielding above average also had canopies of above-average width. It appears that the trees should not be planted less than about 144 inches apart, otherwise it becomes difficult to harvest the crop and to carry on the cultural practices.

The trees produced 3 to 15 stems or scaffold limbs $1 / 2$ inch or more thick within 6 inches from the ground, the average per tree being 7.4. Most of the trees which generally yielded above average also had a number of stems above average.

The average circumference of the stems of each tree varied from 3.4 to 6.4 inches, the grand average being 4.6 inches. Most of the trees which generally yielded above average also had an average circumference of stems above the grand average.

The average length of the primary lateral branches varied from 15.5 to 27.5 inches, the grand average being 22.3 inches. Many of the trees yielding above average also had an average length of primary lateral branches above the grand average.

The average number of spurs or short fruit-bearing stems per primary lateral branch varied from 10.0 to 37.8 , the grand average being 19.7. Most of the trees which yielded above average also had an average number of spurs per primary lateral branch higher than the grand average.

It is evident that the trees which were taller, had wider canopies, a larger number of thick seaffold limbs, and long primary lateral branches with many spurs generally produced larger crops. These characters are influenced by the genetic constitution of the trees and the environmental conditions to which they are subjected. Therefore, to get better results all should be favorable (table 1). 


\section{FiRUIT YILLI)}

Usually fully ripe or partly ripe fruits were harvested. Pickings were made as frequently as seemed necessary. As far as possible every precaution was

ТАнц.: 1.-Characters of 5-year-old acerola tres in the experimental planting at the Agricullural Expcriment Substation, Castañer, P.R., sludied during March 1959

\begin{tabular}{|c|c|c|c|c|c|c|}
\hline Tree No. & Height of tree & $\begin{array}{c}\text { Diameter of } \\
\text { canopy }\end{array}$ & $\begin{array}{l}\text { Stems within } \\
6^{\prime \prime} \text { of ground }\end{array}$ & $\begin{array}{l}\text { Average cir- } \\
\text { cumference of } \\
\text { stems near } \\
\text { ground }\end{array}$ & $\begin{array}{c}\text { Average length } \\
\text { of primary } \\
\text { lateral } \\
\text { branches' }\end{array}$ & $\begin{array}{l}\text { Average spurs } \\
\text { per primary } \\
\text { lateral branch }\end{array}$ \\
\hline & Inches & Inches & Number & Inches & Inches & Number \\
\hline 1 & 92.0 & 87.0 & 8 & 3.5 & 24.3 & 20.5 \\
\hline 2 & 93.0 & 136.0 & 5 & 3.7 & 27.5 & 19.8 \\
\hline 3 & 80.0 & 110.0 & 5 & 4.7 & 21.5 & 22.3 \\
\hline 4 & 85.0 & 125.0 & 8 & 4.2 & 23.3 & 20.3 \\
\hline 5 & 110.0 & 137.0 & 12 & 4.5 & 29.3 & 19.8 \\
\hline 6 & 97.0 & 96.5 & 10 & 3.5 & 22.0 & 15.8 \\
\hline 7 & 90.0 & 73.0 & 5 & 3.4 & 21.0 & 17.0 \\
\hline 8 & 132.0 & 157.0 & 5 & 6.4 & 23.3 & 22.3 \\
\hline 9 & 105.0 & 82.0 & 6 & 4.1 & 23.8 & 14.3 \\
\hline 10 & 109.0 & 97.0 & 9 & 4.2 & 19.5 & 10.0 \\
\hline 11 & 118.0 & 143.0 & 5 & 6.3 & 23.3 & 24.8 \\
\hline .12 & 84.0 & 104.5 & 5 & 4.1 & 21.8 & 12.8 \\
\hline 13 & 76.0 & 101.0 & 5 & 4.3 & 19.0 & 16.8 \\
\hline 14 & 105.0 & $14+.0$ & 8 & 4.2 & 25.3 & 23.5 \\
\hline 15 & 112.0 & 119.5 & 4 & 6.3 & 24.0 & 17.3 \\
\hline 16 & 91.0 & 117.0 & 5 & 4.7 & 21.5 & 18.5 \\
\hline 17 & 82.0 & 90.0 & 3 & 5.6 & 18.3 & 10.0 \\
\hline 18 & 120.0 & 125.5 & 9 & 4.9 & 25.8 & 20.8 \\
\hline 19 & 109.0 & 83.0 & 4 & 4.9 & 15.5 & 19.0 \\
\hline 20 & (14.0) & 115.5 & 8 & 4.8 & 20.8 & 17.8 \\
\hline 21 & 132.0 & 143.5 & 8 & 5.2 & 21.5 & 24.3 \\
\hline 22 & 103.0 & 103.0 & 15 & 4.1 & 24.5 & 26.3 \\
\hline 23 & 101.0 & $1+1.5$ & 14 & 5.0 & 26.0 & 37.8 \\
\hline 24 & 90.0 & 124.5 & 11 & 4.3 & 21.8 & 21.5 \\
\hline Total & $2,410.0$ & $2,756.0$ & 177 & 110.9 & 535.6 & 473.3 \\
\hline A verage & 100.4 & 114.8 & 7.4 & 4.6 & 22.3 & 19.7 \\
\hline
\end{tabular}

1 From cach tree + primary lateral branches arising about the middle of the height of the tree were taken at random for determination of their a verage length and average number of spurs.

taken to weigh all the fruits produced. Some of the trees started bearing fruits at the age of about $21 / 2$ years. However, many of them produced a good crop when about 3 years old. The individual trec-yield data were collected during 19:58 to 1960 . 
During 1958 the yield was relatively low. But during 1959 and 1960 the yields were relatively high and comparable, indicating that the trees had reached full yielding capacity.

No fruits ripened from December to March. Only one tree yielded during April. During May to July almost all the trees produced a fair-sized crop.

TABLE 2.-Fruit yield, in ounces, from acerola trees in the experimental planting at the Agricultural Experiment Substation,

Castañer, P.R., 1958-60

\begin{tabular}{c|r|r|r|r}
\hline Tree No. & 1958 & 1959 & 1960 & Total \\
\hline 1 & - & 5 & 32 & 37 \\
2 & - & - & 34 & 34 \\
3 & - & 73 & 190 & 263 \\
4 & 94 & 289 & 88 & 471 \\
5 & 5 & 511 & 661 & 1,177 \\
6 & 1 & 32 & 180 & 213 \\
7 & 2 & - & 271 & 273 \\
8 & 51 & 938 & 1,251 & 2,240 \\
9 & 75 & 360 & 191 & 626 \\
10 & 111 & 110 & 208 & 429 \\
11 & 290 & 340 & 608 & 1,238 \\
12 & 3 & 42 & 8 & .53 \\
13 & 48 & 35 & 3 & 86 \\
14 & - & .61 & 231 & 292 \\
15 & 360 & 474 & 506 & 1,340 \\
16 & 132 & 425 & 400 & 957 \\
17 & 137 & 147 & 267 & 551 \\
18 & 85 & 336 & 762 & 1,183 \\
19 & 162 & 93 & - & 255 \\
20 & 362 & 797 & 626 & 1,785 \\
21 & 918 & 2,024 & 1,928 & 4,870 \\
22 & 683 & 1,532 & 1,852 & 4,067 \\
23 & 701 & 932 & 817 & 2,450 \\
24 & 705 & 533 & 433 & 1,671 \\
\hline Total & 4,925 & 10,089 & 11,547 & 26,561 \\
\hline Average & 205.2 & 420.4 & 481.1 & $1,106.7$ \\
\hline & & & &
\end{tabular}

The crop was best during August. During September to November the crop was again of fair size.

The trees showed great variability as to yield. Some trees were very high yielders, whereas the others produced medium or small-sized crops. It appears that per acre yield can be greatly raised through use of highyielding selections. Improvements in cultural practices may also increase the yield (tables 2 and 3 ). 


\section{FRUIT CHARACTERS}

Samples of 25 ripe fruits per tree were taken on two dates. Diameter of the individual fruits was measured. The trees showed great variability as to the average diameter of their fruits. However, the average diameter of the fruits from the same tree at the two dates did not differ much.

TABLe 3.-Fruit yield, in ounces, from acerola trees in the experimental
planting at the Agricultural Experiment Substation, Castañer, P.R.,
during different months from 1958 to 1960

\begin{tabular}{|c|c|c|c|c|c|c|c|c|c|c|c|c|}
\hline Tree No. & Jan. & Feb. & Mar. & Apr. & May & June & July & Aug. & Sept. & Oct. & Nov. & Dec. \\
\hline 1 & - & - & - & - & - & 2 & - & 35 & - & - & - & - \\
\hline 2 & - & - & - & - & - & - & - & 34 & - & - & - & - \\
\hline 3 & - & - & - & - & - & 32 & 40 & 79 & 37 & 73 & 2 & - \\
\hline 4 & - & - & - & - & 9 & 13 & 100 & 244 & - & 103 & 2 & - \\
\hline 5 & - & - & - & - & - & 46 & 31 & 523 & 151 & 420 & 6 & - \\
\hline 6 & - & - & - & - & 1 & 60 & 25 & 127 & - & - & - & -- \\
\hline 7 & - & - & - & - & 2 & 122 & 18 & 105 & - & 14 & 12 & - \\
\hline 8 & - & - & - & - & 130 & 311 & 24 & 1,071 & 24 & 537 & 143 & - \\
\hline 9 & - & - & - & - & 100 & 51 & 48 & 253 & 9 & 156 & 9 & - \\
\hline 10 & - & - & - & - & 5 & 39 & 21 & 308 & - & 46 & 10 & - \\
\hline 11 & - & - & - & - & 66 & 83 & 193 & 590 & 32 & 272 & 2 & - \\
\hline 12 & - & - & - & - & - & - & 36 & 17 & - & - & - & - \\
\hline 13 & - & - & - & - & 26 & - & 5 & 53 & - & 2 & - & - \\
\hline 14 & - & - & - & - & - & 61 & - & 81 & - & 89 & 61 & - \\
\hline 15 & - & -1 & - & 一 & 92 & 154 & - & 911 & - & 97 & 86 & - \\
\hline 16 & - & - & - & - & 44 & 93 & 122 & 371 & 33 & 217 & 77 & - \\
\hline 17 & - & - & - & - & 56 & 39 & 37 & 277 & 17 & 118 & 7 & - \\
\hline 18 & - & -1 & - & - & 10 & 208 & 4 & 526 & - & 267 & 168 & - \\
\hline 19 & - & - & - & - & 27 & 24 & 30 & 115 & - & 57 & 2 & - \\
\hline 2 & - & -1 & - & - & 264 & 83 & 174 & 763 & 26 & 364 & 111 & - \\
\hline 21 & - & - & - & 85 & 611 & 270 & 600 & 1,811 & 21 & 1,293 & 179 & - \\
\hline 22 & - & - & - & - & 776 & 271 & 406 & 1,555 & 30 & 976 & 53 & - \\
\hline 23 & - & -1 & - & - & 179 & 140 & 209 & 1,348 & 9 & 504 & 61 & - \\
\hline 24 & - & - & - & - & 308 & 113 & 32 & 811 & 7 & 333 & 67 & - \\
\hline Total & - & - & - & 85 & 2,706 & 2,215 & 2,155 & 12,008 & 396 & 5,938 & 1,058 & - \\
\hline Average & - & - & - & 3.5 & 112.8 & 3 & .8 & 500.3 & 16.5 & 247.4 & 44.1 & - \\
\hline
\end{tabular}

Samples of 1 pound of ripe fruits per tree were taken on three dates and the number of fruits counted to calculate their average weight. The trees showed great variability as to average weight of their fruits, though the average weight of the fruits from the same tree on the three dates also showed some differences.

On two dates samples, each of 10 to 22 fully developed fruits, were taken and their vitamin $\mathrm{C}$ contents were determined. The trees showed great 
variability in vitamin $\mathrm{C}$ contents of their fruits. Fully ripe fruits generally had lower vitamin $\mathrm{C}$ contents than the partly ripe furits from the same tree (table 4).

TABLE 4.-Characters of acerola fruits from the experimental planting at the Agricultural Experiment Substation, Castañer, P.R., studied on different dates during 1959

\begin{tabular}{|c|c|c|c|c|c|c|c|c|c|}
\hline \multirow[t]{2}{*}{ Tree No. } & \multicolumn{3}{|c|}{$\begin{array}{l}\text { Average diameter or width } \\
\text { of ripe fruits }\end{array}$} & \multicolumn{4}{|c|}{ Average weight of ripe fruits } & \multicolumn{2}{|c|}{$\begin{array}{l}\text { Vitamin } C \text { in } 100 \\
\mathrm{gm} . \text { of }\end{array}$} \\
\hline & Aug. 19 & Aug. 24 & $\begin{array}{l}\text { Average } \\
\text { of } 2 \\
\text { samples }\end{array}$ & Aug. 17 & Aug. 19 & Aug. 24 & $\begin{array}{c}\text { Average } \\
\text { of } 3 \\
\text { samples }\end{array}$ & $\begin{array}{l}\text { Fruits fully } \\
\text { ripe Oct. } 14\end{array}$ & $\begin{array}{l}\text { Furits par- } \\
\text { tially ripe } \\
\text { Oct. } 22\end{array}$ \\
\hline & $\Delta f m$. & $M m$ & $\Delta / m$. & $G m$. & Gm. & $G m$. & $\mathrm{Gm}$. & $\Delta I g$. & IIg. \\
\hline 1 & - & - & - & - & - & - & - & - & - \\
\hline 2 & - & - & - & - & - & - & - & - & - \\
\hline 3 & - & - & - & 4.1 & - & - & 4.1 & - & 1,582 \\
\hline 4 & 20.6 & 20.3 & 20.5 & 4.1 & 3.9 & 3.3 & 3.8 & 1,061 & 1,897 \\
\hline 5 & 20.7 & 21.1 & 20.9 & 6.7 & 5.7 & 4.5 & 5.6 & 1,197 & 1,956 \\
\hline 6 & - & - & - & - & - & - & - & - & - \\
\hline 7 & - & - & - & - & - & - & - & - & - \\
\hline 8 & 18.3 & 17.8 & 18.5 & 2.6 & 3.4 & 1.9 & 2.6 & 917 & 1,399 \\
\hline 9 & 20.4 & - & 20.4 & 4.9 & 4.5 & 一 & 4.7 & 600 & 1,046 \\
\hline 10 & - & 21.8 & 21.8 & 5.7 & - & 3.9 & 4.8 & - & 1,489 \\
\hline 11 & - & - & - & 4.4 & 一 & - & 4.4 & 945 & 1,811 \\
\hline 12 & 一 & 一 & - & - & - & - & - & - & - \\
\hline 13 & 一 & - & - & 2.3 & - & - & 2.3 & - & - \\
\hline 14 & - & 一 & - & - & - & - & - & 929 & - \\
\hline 15 & 20.6 & 19.7 & 20.2 & 一 & 4.9 & 2.8 & 3.9 & - & 1,444 \\
\hline 16 & 22.1 & 22.1 & 22.1 & 5.2 & 5.7 & 4.2 & 5.0 & 611 & 1,608 \\
\hline 17 & 21.8 & - & 21.8 & 5.7 & 4.9 & - & 5.3 & 1,093 & 1,482 \\
\hline 18 & 20.8 & 21.6 & 21.2 & 5.0 & 4.5 & 6.7 & 5.4 & 1,272 & 1,853 \\
\hline 19 & 19.8 & 20.7 & 20.3 & 4.1 & 3.9 & 2.6 & 3.5 & - & - \\
\hline 20 & 17.6 & 18.4 & 18.0 & 3.2 & 3.4 & 1.7 & 2.8 & 1,385 & 1,987 \\
\hline 21 & 20.2 & 19.7 & 20.0 & 3.0 & 3.3 & 2.6 & 3.0 & 1,296 & 1,676 \\
\hline 22 & 22.2 & 22.0 & 22.1 & 4.7 & 5.7 & 3.5 & 4.6 & 1,369 & 1,834 \\
\hline 23 & 20.6 & 20.9 & 20.8 & 3.4 & 4.5 & 2.8 & 3.6 & 1,194 & 1,930 \\
\hline 24 & 16.8 & 16.7 & 16.8 & 1.6 & 2.0 & 1.6 & 1.7 & 1,218 & 2,097 \\
\hline Total & 282.5 & 262.8 & & 70.7 & 60.3 & 42.1 & & 15,087 & 27,091 \\
\hline $\begin{array}{l}\text { Average of } \\
\text { samples } \\
\text { taken }\end{array}$ & 20.2 & 20.2 & & 4.2 & 4.3 & 3.2 & & $1,077.6$ & $1,693.2$ \\
\hline
\end{tabular}

\section{UTILIZATION OF FRUITS}

The fruits from the experimental planting were utilized for preparing juice, jellies, and such, on a home scale by most of the cooperators to whom they were supplied. Many persons liked to eot the fruits fresh, especially 
those of large size and less acidity. However, the demand for fruits for these purposes was quite limited.

\section{DISEASES AND INSECT PESTS}

Old leaves on some of the trees, especially during January and February, had small yellow spots possibly caused by a fungus (Cercospora).

Occasionally the skippers (Hesperiidae) ate parts of leaves on some of the trees.

Sometimes birds caused slight damage to the ripe fruits.

Most of the trees did not suffer seriously from any disease or insect pest. Therefore no spraying of any kind was carried on.

\section{POSSIBILITIES OF COMMERCIAL ACEROLA PRODUCTION IN THE COFFEE REGION}

In this Region coffee is the only crop of great economic importance. It is highly desirable that the farming should be thoroughly diversified to improve the economic conditions of the Region. Under any program for this purpose emphasis should be placed on encouraging the commercial production of fruit crops which grow well here.

The present study indicates that acerola can be commercially grown in this Region if the fruits can be sold to some canning or other processing concerns such as now exist in some other parts of the Island where acerola is now commercially grown.

\section{SUMMARY}

The performance of acerola (Malpighia punicifolia L.) was studied for 7 years at Castañer, located in the centre of the Coffee Region of Puerto Rico.

The acerola plants were raised from seed of clone B-17. They were planted in the field in an Alonso clay soil with a $\mathrm{pH}$ of about 5.0. To avoid soil erosion the planting was not cultivated. However, the other cultural practices such as cutting of weeds, application of fertilizer, and so on were properly attended.

The acerola trees showed great variability as to height, diameter of canopy, number and thickness of scaffold limbs, length of primary lateral branches, and number of spurs.

The acerola trees started bearing well when about 3 years old. The crop was harvested from April to November, with peak production in August.

The acerola trees showed great variability as to fruit yield. Over a 3-year period their average annual fruit yield varied from 205.2 to 481.1 ounces.

The trees also showed great variability as to the average diameter and weight of their fruits. However, the diameter and weight of fruits harvested from the same tree on different dates did not vary much. 
The acerola trees displayed great variability as to vitamin $\mathrm{C}$ contents of their fruits. Fully ripe fruits generally had lower vitamin $\mathrm{C}$ contents than the partly ripe fruits from the same tree.

The acerola fruits were utilized for preparing juice and jelly on a home scale. Many persons liked to eat fruits fresh, especially those of large size and lower acidity.

There was no serious incidence of diseases and insect pests in the acerola planting.

The present study indicates that acerola can be commercially grown in the Coffee Region of Puerto Rico, provided the fruits can be sold to some canning or other processing concern.

\section{RESUMEN}

Durante 7 años se estudió el comportamiento de la acerola (Malpighia punicifolia L.) en la Subestación de Castañer ubicada en el centro de la región cafetalera de Puerto Rico.

Las plantitas de acerola provinieron de semillas del clon B-17. Se sembraron en el campo en un tipo de suelo Alonso arcilloso cuyo $\mathrm{pH}$ era alrededor de 5.0. Como el terreno era en declive, la siembra se dejó sin cultivar para evitar la erosión, aunque otras prácticas como la erradicación de los yerbajos, el abonamiento, etc., se atendieron debidamente.

Hubo gran variación entre los árboles de acerola en cuanto a tamaño, diámetro del dosel, número y grosor de las ramas escalonadas, longitud de las ramas laterales y número de espolones.

Empezaron a producir frutas cuando tuvieron alrededor de 3 años. La cosecha empezó en abril, continuó hasta noviembre y llegó a su apogeo en agosto.

Los árboles también demostraron gran variación en sus rendimientos de frutas. A través de un período de 3 años, el promedio anual de producción por árbol fluctuó entre 205.2 y 481 onzas.

En promedio, los árboles de acerola demostraron una gran variación en el diámetro y peso de las frutas. Sin embargo, no varió mucho el diámetro ni el peso de las frutas cosechadas de los mismos árboles en fechas distintas.

Estos árboles sí revelaron una gran variación en el contenido de vitamina $\mathrm{C}$ de sus frutas. Las bien maduras tenían menos cantidad de vitamina $\mathbf{C}$ que las que, en el mismo árbol, habían madurado sólo parcialmente.

Las frutas se utilizaron para preparar jugos y jaleas en pequeña escala. A muchas personas les gusta comer la fruta fresca, especialmente las más grandes y las menos ácidas.

Por lo demás, los árboles bajo estudio no sufrieron daño importante debido a enfermedades o a plagas de insectos.

Este estudio indica que la acerola podría cultivarse comercialmente en la 
región cafetalera de Puerto Rico, si la producción lograra venderse para fines industriales.

\section{LITERATURE CITED}

1. Aróstegui, F., Asenjo, C. F., Muñiz, A. I., and Alemañy, L., Observations and data on a promising selection of the West Indian Cherry, Malpighia punicifolia L., J. Agr. Univ. P.R. 39 (2) 51-6, 1955.

2. Aróstegui, F., and Pennock, W., The Acerola, Univ. P.R., Agr. Exp. Sta., Misc. Pub. 15, 1955.

3. Moscoso, Carlos G., West Indian Cherries and the Production of Ascorbic Acid, Univ. P.R., Agr. Exp. Sta., Misc. Pub. 2, 1950.

4. - - West Indian Cherry-Richest known source of natural vitamin C., Econ. Bot. 10 (3) 280-94, 1956.

5. Puerto Rico, Acerola, Compendio de Recomendaciones para la Producción de Cosechas, Univ. P.R. Agr. Exp. Sta. Misc. Pub. 1, 72-77, 1954. 